\title{
Intelligibility: The Goal of Language Learning and Teaching
}

\author{
Sayyed Rashid Shah \\ English Language Institute, King Abdul-Aziz University, Jeddah 21589 \\ PO Box 80200, Saudi Arabia \\ E-mail: srshah@kau.edu.sa \\ Abdullah Al-Bargi \\ English Language Institute, King Abdul-Aziz University, Jeddah 21589 \\ PO Box 80200, Saudi Arabia \\ E-mail: aalbargi@kau.edu.sa
}

Received: February 2, 2016 Accepted: February 16, 2016 Published: February 17, 2016

doi:10.5296/jsel.v4i1.9045 URL: http://dx.doi.org/10.5296/jsel.v4i1.9045

\begin{abstract}
This action research study investigates the intelligibility of Saudi EFL learners' speeches in relation to the Lingua Franca Core (LFC). This study is carried out in an EFL class of 15 Saudi learners. One native and four non-native speakers of English performed the role of evaluators. A mixed-method approach was adopted to collect and analyze quantitative and qualitative data. The learners' scores in their pre and post-intervention speeches led to the understanding of the impact of LFC on leaders' speeches. The scores were awarded by five evaluators responding to a five-point Likert scale questionnaire while judging learners' intelligibility. The results showed moderate improvement in the learners' post-intervention speeches in terms of intelligibility. This procedure was followed by semi-structured interviews conducted with individual evaluators/listeners who rated post-intervention speeches as well-organized, lengthier and planned, delivered fluently and confidently in spite of insignificant improvement in the production of LFC features. Based on the findings, it can be recommended that LFC can have little or no impact on the learners' pronunciation, thus intelligibility should be the goal of language teaching and learning in EFL settings.
\end{abstract}

Keywords: intelligibility, comprehensibility, pronunciation, lingua franca core, non-native speakers, EFL context 


\section{Introduction}

Pronunciation has always been considered a challenging area for both teachers and learners, especially in the EFL context where other skills tend to be given more consideration. Its importance has been revived and been the subject of increased investigation, study and emphasis over the past thirty years in the ELT domain. It is widely acknowledged that learners of all levels should be taught pronunciation, as faulty pronunciation may lead to simple communication breakdowns. Therefore, if the pronunciation instruction becomes an 'integral part of [the] oral communication', learners can perform better both in classroom as well as outside (Morley 1991, p. 496). Researchers suggest that learners are not required to emphasize pronunciation at the expense of other skills with a view to acquiring native-speaker-like pronunciation, but that their achieving mere intelligibility will serve their purpose. Celce-Murcia, Brinton, and Goodwin (1996) point out that L2 learners of English require to reach a "threshold level of pronunciation" to be intelligible to others. This is arguably the primary goal of teaching and learning pronunciation, specifically where learners have had little pronunciation instruction in context during their school years. Their exposure at that time is limited to classroom practice only and is of course adversely impacted where their L1 sound system completely differs from that of the target language.

Not surprisingly, the communicative approach has dominated EFL clasisroom practice for decades. Its mode of instruction has emphasized communication by means of the target language. Although, it does not explicitly concentrate on pronunciation instruction, nonetheless, its role has been considered significant in regard to effective and comprehensible communication in foreign language teaching (Carey 2002:3). Since sounds are considered of paramount importance in communication, EFL teachers must pay attention to the essential features; segmental \& prosodic, of pronunciation. It is important that speakers and hearers understand each other and produce the target language sounds accurately for intelligible communication. In order to encode and decode a message correctly, learners have to master the sound patterns of the target language. Gilbert (1984) affirms that the skills of listening comprehension and pronunciation are interdependent: "If they cannot hear English well, they are cut off from the language...If they cannot be understood easily, they are cut off from conversation with native speakers" (p.1).

While replicating the findings by Zoghbor (2010), the key aim of the study is to investigate the influence on pronunciation teaching on the EFL learners' intelligibility. The reviewed literature in the following section highlights certain domains in teaching pronunciation. Firstly, it accentuates the significance of teaching and learning pronunciation in the EFL context. Secondly, it discusses theories; supporting and proposing intelligibility as a goal of teaching and learning pronunciation in EFL classrooms. Thirdly, it investigates factors which can potentially affect learners' goals of achieving native-like pronunciation. Fourthly, it proposes a model of Lingua Franca Core (LFC) for teachers to exploit in their classrooms, with a special focus on features relating to learners' intelligibility and on the applicability of this model for the learning situations and primary perspectives of non-native speakers. Finally, it considers specifically Arab learners' pronunciation deficiencies, i.e. segmental and suprasegmental, which essentially influence their speech intelligibility. 


\section{$\Lambda$ Macrothink}

1.1 Research Questions

2016, Vol. 4, No. 1

Does Lingua Franca Core ( $L F C$ ) help to improve the learners' intelligibility as a result of classroom instructions?

What are the listeners' perceptions of EFL learners' intelligibility in their speeches?

\section{Context of the Study}

In Saudi Arabia, although the government authorities have come to realize the importance of English language in times recent, Arabic is still the main language for communication in the Kingdom and its neighboring gulf states. It is the language of the Holy Quran and hence, is deemed a holy language. In Saudi schools and universities, Arabic is the language of teaching for almost all the subjects and students get their first exposure to English language at the age of 12 in schools. When they enter the universities where they have to take the mandatory foundation year courses, they are equipped with 6 to 7 years of English learning.

This action research study is carried out in the English Language Institute (ELI) at King Abdul-Aziz University, Jeddah, Saudi Arabia. At the ELI, there are about 300 male teachers from 25 different countries with various L1 backgrounds and this number is enormously growing. Likewise, every year nearly 7000 students enroll in the preparatory year programme where they take 18 hours of English language classes per week.

At the ELI, prior to the enrollment in the foundation year programme, students take the Oxford Placement Test designed by the University of Oxford. Achieved grades demonstrate their levels of English proficiency which help stream them into appropriate levels; beginners, elementary, pre-intermediate and intermediate. It is observed that more than $70 \%$ of the students are usually placed in lower levels as they mostly lack motivation (Shah et al, 2013). In a modular system, learners remain in one level for a module of six teaching weeks before they are promoted to another level. The Oxford Headway Plus (Special Edition) textbook is adopted for teaching beginner, elementary, pre-intermediate and intermediate level students at the ELI.

\section{Literature Review}

This section of the paper explores relevant literature on the use of LFC and develops a conceptual and theoretical framework for the study. The opening section highlights the importance of teaching and learning pronunciation and introduces the concept of intelligibility in general. Then, the core contents of LFC followed by the Arabic phonology which is of course the learners' L1 and relevant to this study.

\section{The Significance of Teaching and Learning Pronunciation}

In many language classrooms, pronunciation has been ignored due to a variety of reasons. For example: lack of teachers' and learners' motivation, inadequacy or lack of professional training for teachers, teachers own deficient pronunciation or inadequate or irrelevant instructional materials and textbooks.

Despite the fact that pronunciation has received little attention in foreign language teaching, it 
has always been part of language classrooms in one way or another. Its history signifies its role in the context of second language teaching as commented by Seidlhofer (2001, p. 56), it "stood at the very beginning of language teaching methodology as a principled, theoretically-founded discipline, originating with the late-nineteenth-century Reform Movement". Reform Movement phoneticians who supported the teaching and learning of pronunciation reached a consensus on its significance in second language instruction, (see Collins and Mees 1999; Howatt, 2004).

The significance of teaching pronunciation is reviewed in literature which highlights its role in language curriculums. It is believed that teachers and learners should pay attention to its necessary components. "Pronunciation should be taught in all second language classes through a variety of activities" (Scarcella \& Oxford, 1994). However, in contrast to what Scarcella \& Oxford (ibid) say, it is seen that the textbooks do not offer a variety of activities in 'pronunciation sections', i.e. OUP (Oxford University Press) Headway Plus contain identical exercises which sound monotonous at times. Moreover, they rarely fulfil the learners' basic needs in EFL contexts.

However, researchers and material designers have agreed that making pronunciation an integral part of curriculum has lasting effects on learners' communication skills. In this regard, there are two pre-eminent principles regarding teaching and researching pronunciation, 'the nativeness principle' and 'the intelligibility principle' (Levis, 2005). In the former, it is claimed that L2 learners can achieve native-like accents whereas the latter principle claims that learners' need to be understood. Many researchers indicate that "nativeness" is an unachievable task for the L2 learners (Scovel, 2000), even so"nativeness principle" dominates today's pronunciation instruction (Levis, 2005). Although, factors such as motivation, L2 exposure, and formal training in pronunciation can have a positive impact on the learners' accent, they cannot overcome the age factor (Moyer, 1999) which can possibly demoralize learners. Therefore, Moyer (1999) suggests "At best, perfectionist performance goals turn out to be unrealistic; at worst, they can be devastating: They can defeat students who feel that they cannot measure up, and they can frustrate teachers who feel they have failed in their job" (p. 498). However, the goal of attaining native-like pronunciation/accents is somehow achievable for learners in ESL context, i.e. UK, USA, and New Zealand where they have plenty of opportunities to interact with native speakers outside their classrooms. On the other hand, EFL learners in countries like Saudi Arabia, Oman and Afghanistan mainly continue to rely on classroom instruction, electronic media, videos and movies etc. Therefore, teachers need to avoid frustrating their learners and rather raise their awareness of the importance of intelligibility in EFL context.

In the light of the above findings, it is recommended that realistic, easily attainable teaching and learning goals are set. Morely (1991, p. 500) states that the goal of teaching and learning of pronunciation in the classroom should not be achieving 'perfect accent' but should rather seek to improve functional intelligibility and communicability and increase self-confidence.

\subsection{Intelligibility}

It is difficult to define intelligibility as academic literature demonstrates a lack of consensus 
among scholars and a failure to agree on one definition. According to Smith and Nelson (1985), the terms intelligibility and comprehensibility are often used interchangeably. They propose that intelligibility refers to the recognition of word forms, utterances and expressions whereas comprehensibility means the construction of meanings. Similarly, Munro and Derwing (1995) also reach the conclusion that intelligibility is measured by the learners' ability to transcribe the actual words of an utterance whereas comprehensibility is measured by an overall rating of understanding of a given speaker. More recent research on the issue of intelligibility has explored it as learners' endeavour to make them understood to others and especially to 'native' speakers of English. However, Jenkins (2000) broadens her definition of intelligibility which she calls "a dynamic construct in which listener and speaker negotiate word and utterance recognition". She makes it clear from two aspects where simple identification of words and the importance of listener's role are highlighted.

In ESL or EFL contexts, improved learner intelligibility is generally considered as a desirable outcome of pronunciation teaching. Abercrombie (1949) made a point that "language learners need no more than a comfortably intelligible pronunciation" (p. 120). Morely (1991) supports his idea and states that, "Intelligible pronunciation is an essential component of communication competence". Many more studies claim that intelligibility should be the ultimate goal of adults learning English in ESL or EFL contexts (Dalton \& Seidhofer, 1994; Derwing, 2003; Jenkins, 2000; Morely, 1991). Realization of such a goal enables them to communicate effectively in foreign language contexts. It can be seen in the case of foreign graduate students in UK universities whose first aim is to be understood rather than to acquire the speech characteristics of native speakers.

Generally, intelligibility of a speaker is dependent on the degree of listener's understanding (Munro \& Derwing, 1999) which is thought to be an ultimate goal of teaching in classrooms. (Levis, 2005). Such a realistic goal can maximise learners' opportunities to learn and practice pronunciation tasks in the classroom. Moreover, learners are able to gain more confidence by setting and achieving realistic goals such as 'international intelligibility' in the EFL context.

On the other hand, the principle of 'nativeness' as mentioned above continues to persists in classroom instruction as practitioners believe that intelligibility should not be the only goal of L2 learners (Levis, 2005). Harmer (2001) also advises that L2 learners of English should not be denied the possibility as well as opportunity of acquiring or learning native-like pronunciation if they are sufficiently motivated to make the required efforts. Though this is in fact achievable, research demonstrates that there are various factors involved which can possibly adversely affect achievement of learners' goals of attaining native-like pronunciation/accents.

\subsection{General Perception of Intelligibility}

L2 learners are driven by their learning beliefs, attitudes, aims and perceptions which are all significant factors involved in their learning and need to be taken into account by researchers, teachers and educators.

During the last decade, researchers have expressed interest in learners' attitude towards 
pronunciation and its goals. Most results demonstrate that learners aspire to speak in the same or a similar manner as native-speakers. Timmis' (2002) study on learners' attitudes towards pronunciation concludes that students and teachers are more inclined to achieve native-like proficiency through classroom instructions.

The influential Derwing (2003) study claims that almost half of the informants (Immigrants to Canada) view and native-like pronunciation/accents as tools for enabling successful communication. He also makes the very important point that native-like pronunciation/accents, although extremely challenging to successfully acquire, entail and generate respect and social status.

This discussion section closes with Ur's (1996, p. 52) decisive comments that "It needs to be said that the aim of pronunciation improvement is not to achieve a perfect imitation of a native accent, but simply to get the learner to pronounce accurately enough to be easily and comfortably comprehensible to other (competent) speakers. 'Perfect' accents are difficult if not impossible for most of us to achieve in an EFL context anyway, and may not even be desirable. Many people, even if subconsciously, feel they wish to maintain a slight mother-tongue accent as an assertion of personal identity".

\subsection{Pronunciation Model: Lingua Franca Core}

In spite of extensive research conducted on intelligibility in the domain of teaching pronunciation, practitioners, researchers and educators still lack consensus on a particular construct in order to promote its primary goal. Jenkins (2000) proposes a model called Lingua Franca Core (LFC), which advises teachers not to restrict learners merely to emulating and aspiring to produce British $\mathrm{RP} / \mathrm{BrE}$ or General American GA/AmE pronunciation/accents. In fact, her LFC model ensures L2 learners' performance validity and identity in most favourable situations where they are able to still achieve their primary goal of intelligibility. Importantly, Jenkins' syllabus focuses on L2 learners, who chiefly interact with L2 speakers hailing from different L1 backgrounds. So, 'native' speakers of English are not necessarily considered here. Jenkins (2006) believes that this model equips L2 speakers to articulate their 'identity and affiliation with the international community'. It also enables speakers to remain intelligible to listeners. Jenkins (2000) argues that the main issue of intelligibility in the English as an International Language (EIL) context is pronunciation. Therefore, she identifies key areas in Table 1 which require attention in the interests of international intelligibility.

Table 1. Pronunciation targets for teaching EFL - Modified from Jenkins (2005, p. 147)

\begin{tabular}{|c|c|c|c|c|}
\hline \multirow[b]{2}{*}{ \# } & $\mathbf{A}$ & B & C & D \\
\hline & Aspects of Pronunciation & EFL Targets & $\begin{array}{l}\text { Influence on } \\
\text { Intelligibility }\end{array}$ & EFL Targets \\
\hline \multirow[t]{2}{*}{1} & \multirow{2}{*}{$\begin{array}{l}\text { The Consonantal } \\
\text { Inventory }\end{array}$} & All Sounds & $\begin{array}{l}\sqrt{ } \\
\text { but not all }\end{array}$ & $\begin{array}{l}\text { All sounds except } / \Theta / \\
\text { and /ð/ }\end{array}$ \\
\hline & & $\begin{array}{l}\text { RP non-rhotic } / \mathrm{r} / \\
\text { GA rhotic /r/ }\end{array}$ & $\begin{array}{l}\sqrt{ } \\
\text { but not all }\end{array}$ & Rhotic/r/ only \\
\hline
\end{tabular}




\begin{tabular}{|c|c|c|c|c|}
\hline & & $\begin{array}{l}\mathrm{RP} \text { intervocalic }[\mathrm{t}] \\
\text { GA intervocalic }[\mathrm{t}]\end{array}$ & $\begin{array}{l}\sqrt{ } \\
\text { but not all }\end{array}$ & Interwocalic $[\mathrm{t}]$ only \\
\hline 2 & Phonetic requirements & Rarely specified & $\begin{array}{l}\sqrt{ } \\
\text { but not all }\end{array}$ & $\begin{array}{l}\text { Aspiration after } / \mathrm{p} / \text {, } \\
/ \mathrm{t} / \text {, and } / \mathrm{k} / \\
\text { Appropriate vowel } \\
\text { length before } \\
\text { Fortis/lenis } \\
\text { consonants }\end{array}$ \\
\hline 3 & Consonant cluster & All word positions & $\begin{array}{l}\sqrt{ } \\
\text { but not all }\end{array}$ & $\begin{array}{l}\text { Word initially, word } \\
\text { medially }\end{array}$ \\
\hline 4 & Vowel quantity & $\begin{array}{l}\text { Long-short } \\
\text { contrast }\end{array}$ & $\sqrt{ }$ & Long-short contrast \\
\hline 5 & Vowel quality & Close to RP or GA & $x$ & $\begin{array}{l}\text { L2 (consistent) } \\
\text { regional qualities }\end{array}$ \\
\hline 6 & Weak forms & Essentials & $\times$ & $\begin{array}{ll}\text { Unhelpful to } \\
\text { intelligibility }\end{array}$ \\
\hline 7 & $\begin{array}{l}\text { Features of connected } \\
\text { speech }\end{array}$ & All & $x$ & $\begin{array}{l}\text { Inconsequential or } \\
\text { unhelpful }\end{array}$ \\
\hline 8 & Stress-timed rhythm & Important & $x$ & Does not exist \\
\hline 9 & Word stress & Critical & $x$ & $\begin{array}{l}\text { Unnecessary/ can } \\
\text { reduce flexibility }\end{array}$ \\
\hline 10 & Nuclear (tonic) stress & Important & $\sqrt{ }$ & Critical \\
\hline
\end{tabular}

Jenkins (2000) makes it clear that LFC "is neither a pronunciation model nor a restricted simplified core" (p. 158). In fact she refers to the most important features which make real difference in international situations using English as a lingua franca. It also signifies the speakers' L1 background which contributes to learners' intelligibility. In the EIL context, however, it is not possible or ideal for teachers to set their own priorities as opposed to selecting features based on learner needs. Therefore, teachers are encouraged to carry out an action research on their learners' pronunciation problems specifically relating to their intelligibility. This is intended to provide factual information on issues and their scope on the most important aspects of pronunciation which can be matched with LFC and applied in classrooms.

\subsection{Response to Lingua Franca Core}

Jenkins' (2000) LFC poses numerous questions, as learners, teachers and researchers have strongly reacted to its model. For example, Dauer (2005) questions its goal of intelligibility for L2 learners. She asks if it benefits both EFL and ESL learners, especially those who travel or study in a foreign country. Moreover, EFL teachers in Jenkins' own study are willing to incorporate the model in their classrooms, but express reservations as to whether or not the LFC meets learners' goals outside the classroom.

Jenkins (2006) reassesses the LFC goals and discovers that the majority of the L2 learners 
oppose the idea of intelligibility as the sole goal of pronunciation teaching and learning, while noting a proportion of learners prefer to retain their own accents. She also observes that GA/AmE and British RP/BrE accents are so widely accepted in English language classroom learning and teaching that other accents are not catered for, especially by non-native teachers. She concludes that LFC implementation in EFL classrooms is beneficial if concerned teachers find it useful as a means of providing their students with actual opportunities to gain 'ownership' of the target language.

So far, it is highlighted in the above section that teaching of pronunciation has definite classroom implications as there remains a perceptible gap between the researchers' findings in the field and classroom dynamics. The situation further is further complicated in EFL contexts, where both learners and teachers strive for 'native-like' pronunciation/accents and hence strive to exceed the goal of intelligibility. The LFC model however can assist EFL teachers to some extent to identify and rectify learners' pronunciation errors and focus on only those problems which are detrimental to intelligibility.

\subsection{Classroom Priorities: Segmental or Superasegmental Features}

Wide-ranging comprehensive research and needs analysis is required to select which pronunciation features should be taught to particular groups of students, with particular emphasis given to learner intelligibility enhancement. Moreover, the importance of either segmental (phonemes) or suprasegmental/prosodic (word stress, rhythm and intonation) have not, as yet, been clearly prioritised by the researchers, which further complicates the picture. However, it is important to understand learners' existing target language knowledge which undoubtedly helps teachers focus on pronunciation features requiring urgent attention.

Hammond (1995), comments that learners of second language are fully able of "perceiving and articulating subtle" differences with adequate clarification (p. 300). If this clarity is forthcoming, the focus should be immediately switched to suprasegmental features since they are more important in communicative teaching as they deal with highlighting stress and intonation which are essential elements in regard to students' abilities to communicate intelligibly. Hammond (ibid) also points out that a teacher should consider the significance of 'sound and meaning' which are the basic linguistic goals of language learners (P.294 and which can only be mastered through teaching suprasegmentally.

Wong (1993, p. 45) asserts that most significant features of pronunciation, i.e. stress, rhythm and intonation play a vital role in communication and enhance learners' intelligibility as opposed to the role played by segmental features, i.e. phonemes or individual sounds.

Anderson-Hsieh's, Johnson's, and Koehler's (1998) study, involving 11 groups of learners, provides results indicating the relative contributions made by the suprasegmental or prosodic pronunciation features. They demonstrate that "prosodic deviance may affect comprehension more adversely than segmental deviance" (p. 562).

Similarly, Derwing's, Munro's and Wieb's (1998) study examines the effects of both segmental and suprasegmental classroom instructions on learners' intelligibility. They conclude that suprasegmental instruction has greater positive impact on learners' 
performances specifically in oral and communicative tasks.

It is evident from the above findings that EFL teachers and learners should pay increased attention to prosodic English language features as they enhance communication and intelligibility. The LFC model however does not sufficiently emphasise suprasegmental aspects of pronunciation teaching, with the exception of "nuclear stress" in the interests of intelligibility.

\section{Methodology}

This study adopts a mixed methods research design (Creswell, 2014) and aims at exploring the perceptions EFL teachers regarding the speech intelligibility of intermediate level EFL learners in the Saudi context. The quantitative data were collected using a five-points Likert scale which was followed by semi-structured interviews. As semi-structured interviews 'offers a compromise between the two extremes' (Dornyei, 2007, p. 136), which fitted the purpose of this study.

\subsection{Data Collection Procedures}

For the purpose of this study, LFC features were integrated into pronunciation activities given in the Headway Plus (intermediate). The customised learning activities allowed the teacher to ensure that all features of LFC were covered. Learners were encouraged to produce, correct and reflect on their pronunciation. Exercises used in 'English Pronunciation in Use' by Hankook, 'Pronunciation in Use' by Hewings (2007) and 'English Pronunciation Made Simple' by Dale and Poms (2005) were integrated with exercises used in the Oxford Headway Plus (Special Edition) by Liz and Soars (2011) for pre-intermediate students at the ELI.

In the first stage of data collection, pre-intervention data was collected from 14 EFL learners. They were given a range of topics to choose from and speak about them. Each student selected one topic and presented it to the class. For post-intervention data collection, similar procedure was followed; however, the topics were based on the themes covered in the syllabus. It was assumed that learners would feel motivated to prepare themselves well for oral examination which was conducted the following day.

Pre-intervention speech duration ranged from 30 seconds to 1 minute whereas post-intervention speeches were a bit long. They were digitally recordedl on Olympus MP3 recorder and copied onto a password protected HP computer. All the speeches were labeled with students' pseudonyms.

\subsection{Research Instrument}

The present study adopted a five-point Likert scale procedure. The questionnaire was used by Zoghbor (2010) for the same purpose. However, we modified it after consulting experienced colleagues. Firstly, the questions were rephrased and simplified. Secondly, the rating choices were changed to clear the ambiguity and make the judgment more precise and accurate. Both questions subscribe to the definition of intelligibility and comprehensibility by Smith and Nelson (1985). 
Intelligibility: The ability of the listener to recognize individual words or utterances in a speech Comprehensibility: The ability of the listener to comprehend the meaning of the word or utterance in its given context (Smith \& Nelson, 1985, Cited in Zoghbor 2010).

\subsection{Participants}

To execute LFC, evaluate its effectiveness and assess the learners' intelligibility and comprehensibility, pre-intermediate level students were the only available group since I had no option to teach a particular group of learners rather it was on the discretion of the authorities. Owing to the nature of action research, I had complete access to my own class of twenty students; however, only fifteen students aged 18-21 expressed their interest in the project. All the informants were Saudi nationals who spoke Arabic as their L1.

Five purposively chosen listeners/evaluators who judged the intelligibility and comprehensibility of the learners through a five-point Likert scale, participated in the semi-structured interviews. With regards to the evaluators' expertise, they all had master degrees either in TESOL, applied linguistics or linguistics with solid background knowledge of English phonetics and phonology.

\subsection{The Procedure for Data Presentation}

For the data presentation, MS Excel is used. In order to make the graphic representation of the data reader friendly, data figures are given different values from 5 to 1 . In contrast to the Likert scale questionnaire, the most intelligible speech is given 5 and the least intelligible speech is given 1 value. Each student is assessed by five different evaluators. Thus their responses $(\sqrt{ })$ to the Likert Scale questionnaire are valued and counted. Then, the total score is graphically presented. For example, the score of Ali is 21 .

\begin{tabular}{|l|l|l|l|l|l|l|}
\hline Name & Very easy & Easy & Average & Difficult & $\begin{array}{l}\text { Very } \\
\text { difficult }\end{array}$ & Total \\
\hline Ali & $\sqrt{ } \sqrt{ }$ & $\sqrt{ } \sqrt{ }$ & $\sqrt{ }$ & & \\
\hline Formula & $5+5$ & $4+4$ & 3 & & & 21 \\
\hline
\end{tabular}

Same procedure is followed for pre and post intervention speeches.

All five interviews are transcribed. The transcription is linked to the interpretation and relevance of the research questions by concentrating on the phonological remarks made by the interviewees which are subject to content analysis, 'an approach to the analysis of documents and texts that seeks to quantify content in terms of predetermined categories and in a systematic and replicable manner' (Bryman, 2001, p. 274). The collected data mainly reflect the interviewees' perceptions of the intelligibility of the EFL learners.

Evaluators used separate questionnaires for individual students both at pre and post intervention stages of data collection. This allowed us to measure the individual students' speech intelligibility and present the data into two separate graphs.

\subsection{Ethical Considerations}

Ethical issues were considered before the start of the study. Each individual signed a consent 


\section{Macrothink}

form. Prior to the research, the formal written consents of the Dean of the ELI, students and colleagues (evaluators) were sought. The participants were guaranteed confidentiality of their information and identities (Neuman, 2006). At the time of data analysis, the participants' anonymity was prioritized by using their pseudonyms.

\section{Findings and Discussions}

This section of the paper presents the qualitative and quantitative findings of the action research into two parts: the numerical data obtained through a questionnaire and the findings of semi-structured interviews.

\subsection{Quantitative Data Presentation}

To examine the difference between pre and post intervention speeches of the individual learners, the MS Excel graphic representation is used. Figure 1 represents the scores of intelligibility and figure 2 delineates the scores of comprehensibility. The difference between the pre and post intervention speeches of the pre-intermediate level Saudi EFL learners' intelligibility is summarized in the chart below.

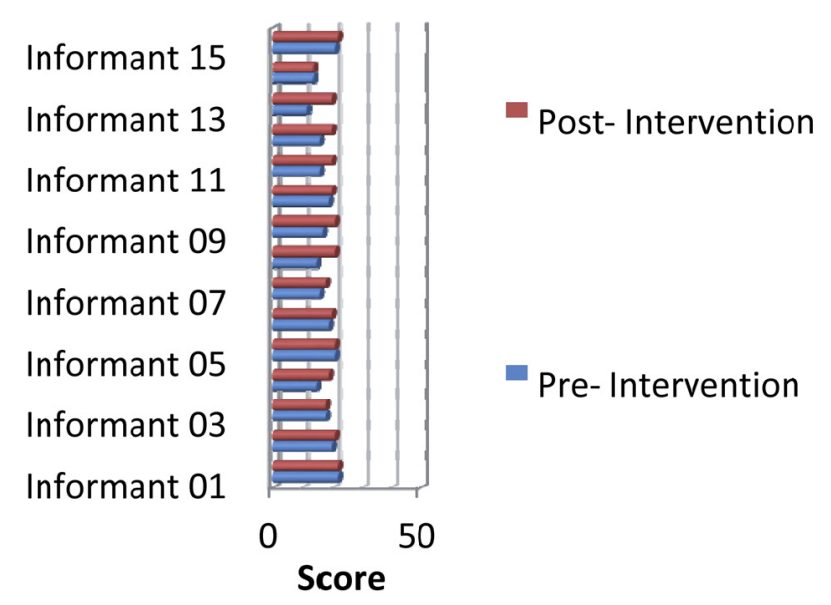

Figure 1. The intelligibility score of the learners

The above chart delineates the intelligibility scores of the informants in their pre and post intervention audio speeches. Based on the five evaluators' understanding of the speeches, the scores suggest that the difference varies from informant to informant. The blue bars indicate pre-intervention scores whereas the red ones show the post intervention scores of the learners.

It is evident from the chart that there is no difference in speech intelligibility of the informants 1, 3, 5 and 14 as their pre and post intervention scores are virtually identical. Similarly, informants 2, 6, 7, 10 and 15 have improved their scores onlly a little. On the other hand, there is a significant difference found in the pre and post intervention speeches of the informants 4, 9, 11 and 12. Moreover, informants 8 and 13 have greatly improved their intelligibility scores in their post intervention speeches. The difference between the pre and post intervention speeches of the pre-intermediate level Saudi EFL learners' comprehensibility is summarized in figure 2 . 


\section{MInstitute Macrothink $^{\text {Int }}$}

Overall, not significant improvement can be noticed in the learners' pronunciation in terms of their intelligibility and thus, the impact of LFC on the learners' accent and intelligibility was insignificant.

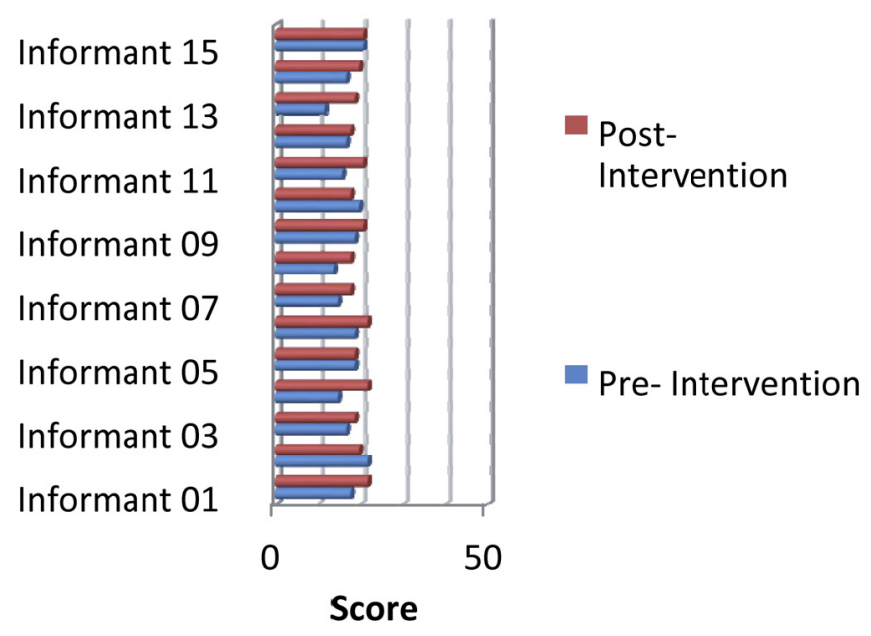

Figure 2. The comprehensibility score of the learners

Resembling the intelligibility scores, the above chart indicates variation in the learners' comprehensibility of the speeches. No significant difference is found in the pre and post intervention speeches of informants 5 and 15. Surprisingly, there is an obvious decrease in the comprehensibility scores of informants 2 and 10. On the other hand, informants 3, 9, 12 and 14 have managed to improve, but very little. However, considerable improvement can be seen in the post intervention results of the informants 1, 6, 7 and 8. Similarly, informants 4, 11 and 14 have improved their comprehensibility scores a great deal.

Overall, the influence of LFC in terms of learners' speech comprehensibility is insignificant as the listeners did not notice much improvement in the learners' speech.

\subsection{Analysis and Discussions of the Questionnaire and Semi-structured Interviews Findings}

This study partially supports the work by Jenkins (2000, 2005, 2007; Zoghbor, 2010). The empirical data collected in her studies show improvement in learners' intelligibility. However, in this study there is moderate improvement in speech intelligibility and comprehensibility of most students and very few learners have shown significant progress as a result of classroom instruction.

There can be various factors that might influence the listeners' understanding of the speeches. It is worth mentioning that all 5 listeners have had extensive experience of teaching Arab EFL learners, which might have improved their intelligibility and comprehensibility of the speeches. As found by Zoghbor (2010), this study also supports the definition of 'intelligibility' stated by Bamgboose (1985) 'as a complex of factors comprising recognizing an expression, knowing its meaning, and knowing what that meaning signifies in the sociocultural context' (p.11). The listeners who have taught the Arab EFL learners have a 
good understanding of their sociocultural context. Therefore, they found it easy to understand expressions and their meanings in a given context.

Due to my exposure to Arabic English, I find it easy to understand Arab speakers because I have developed good knowledge of their culture' Evaluator 1.

The above quote indicates that constant interaction with Arab speakers has helped the listeners understand Saudi culture and its version of English which has influenced the intelligibility of the speakers in this action research. This is similar to what Zoghbor (2010) in her research found about her participants whose exposure to Arab culture influenced their understanding of the speakers' speeches.

A number of sentences, phrases or words were considered unintelligible, however, they did not impact the overall comprehensibility of the speeches. On the other hand, there were phrases or sentences which were intelligible, but comprehensibility as a whole was impacted and the message was unclear. This supports the findings by Nelson (2008) who states that an argument might be intelligible but not comprehensible due to its structure. Evaluator 5 noted down number of incomprehensible sentences and phrases where the words were quite intelligible but their meanings in given context were unclear due to its inappropriate structures and thus he declared them as 'misfit' sentences. However, four non-native English speakers have little or no problems to understand the learners whereas evaluator 4 who was a native speaker has found it difficult to rate the questionnaire and thus listened to the tracks more than once.

The EFL teachers' responses suggest that intelligibility was more important than native-like accent as learners in EFL contexts can improve their pronunciation with the help of the teachers and native-like accent may not be a realistic task in EFL settings. A number scholars believe that to effectively teach pronunciation and gain maximum outcomes, the goal should be a realistic one as 'intelligibility' (e.g. Cook, 2002; Levis, 2005; Celce-Murcia et al., 1996; Wells, 2005) which is set by LFC considering native-like pronunciation least important in EIL context. All the evaluators unanimously agreed on this point that learners in learning and teachers in teaching should set an achievable goal which is of course 'intelligible accent'. Evaluator 5 stated that:

My preference is intelligible accent. My aim is to communicate and if the ideas are communicated properly, words are intelligible and sentences are comprehensible then it's good.

Likewise, the evaluator 1 and 3 on this study have the same viewpoint that the accents of the Saudi EFL learners did not impact on their intelligibility. However, evaluators 2, 4 and 5 have opposite opinion:

Yes, the listeners' accents surely influence their intelligibility and comprehensibility because the listener is used certain phonemic patterns whenever he finds something different from that pattern then he finds it very difficult to understand (Evaluatorl).

When the questions was asked to note the learners' difficulties in terms of accurately 
producing individual sounds, the listeners found identical issues as discussed by Kharma and Hajjaj (1997). The listeners' responses suggest that apart from the individual phonemes, learners encounter various difficulties with consonant clusters positioned at the beginning, middle or at the end of words. These are not considered uncommon issues as Jenkins (2000) states that NNSs try to delete or insert syllables in the middle of consonant clusters and the former threats the intelligibility; however, in this study, the listeners believe that such problems did not affect the intelligibility of the learners. Again, this could be due the familiarity of the listeners with the learners' background and context. In terms of suprasegmental features of LFC, learners have shown no improvement in the area of nuclear stress. Perhaps, it is due to the influence of L1 as Kharma and Hajjaj (1997) consider Arabic a syllable-timed language and its intonation pattern is quite similar to English, however, Arab learners face difficulties employing English intonation patterns. Though intonation is not a feature of the LFC, stressing particular words can be equally difficult for Saudi EFL learners.

\section{Limitations of the Study}

Time constrain is considered a major impediment. A module with six teaching weeks is probably inadequate time for the students to materialize their learning. More time would have given the teacher sufficient room to reflect on the learners' anticipated problems and classroom tasks. In addition, it was challenging to integrate the pronunciation activities based on the LFC contents into the teaching pacing guide provided to the teachers by the administration. The teachers are advised to rigidly follow the hourly pacing guide thus, the activities embedded into the pacing guide do not get due time as the main goal is to finish the given syllabus. Similar to the core curriculum, the New Headway Plus (Special Edition) also put less emphasis on pronunciation which explains the students' failures in overcoming their pronunciation problems.

As pronunciation is not tested in oral exams, it has not been included in the core curriculum. Consequently, students lack intrinsic motivation to learn and improve their pronunciation. Generally, students value tasks directly relevant to their testing and exams. Since, pronunciation was neglected it becomes very hard for the teacher to motivate the learners and develop their taste for pronunciation tasks.

\section{Conclusion}

This action research has replicated the study by Zoghbor (2010) and investigated the impact of LFC in improving the intelligibility of the Saudi EFL learners at pre-intermediate level. Based on the qualitative and quantitative findings of the research, it can be said that students have shown moderate improvement in their post-intervention speeches, however the classroom instructions have positively impacted on their pronunciation to some extent. Generally, the post-intervention speeches are rated more intelligible as the individual words have facilitated the comprehensibility of certain sentences. For the evaluators, intelligibility of the learners should be an achievable and substantial goal than native-like accent in EFL context. 


\section{References}

Abercrombie, D. (1949). Teaching pronunciation. ELT Journal, 3, 113-122.

Al-Ani, S. H. (1970). Arabic phonology: An acoustical and physiological investigation (Vol. 61). Walter de Gruyter.

Anderson-Hsieh, J., R. Johnson \& K. Koehler. (1992). The relationship between native speaker judgments of nonnative pronunciation and deviance in segmentals, prosody, and syllable structure. Language Learning, 42(4), 529-555.

Avery, P., \& Ehrlich, S. (1992). Teaching American English pronunciation. New York: OUP.

Bialystock, E. (1997). Anatomy of a revolution. In: Johnson D. M, Erneling C. E, editors. The futureof the cognitive revolution. New York: Oxford University Press, pp. 109-113. (Eds.)

Bongaerts, T., Van Summeren, C., Planken, B., \& Schils, E. (1997). Age and ultimate attainment in the pronunciation of a foreign language. Studies in second language acquisition, 19(04), 447-465.

Carey, Michael. (2002). An L1-specific CALL pedagogy for the instruction of pronunciation withKorean learners of English. Unpublished PhD Dissertation. Macquarie: Macquaire University.

Celce-Murcia, M., Brinton, D. \& Goodwin, J. (1996). Teaching Pronunciation: Reference for Teachers of English to Speakers of Other Languages. Cambridge: Cambridge University Press.

Celce-Murcia, M., Brinton, D., \& Goodwin, J. M. (1996). Teaching pronunciation: $a$ reference forteachers of English to speakers of other languages. Cambridge University Press.

Cook, V. (2002). Language teaching methodology and the L2 user perspective. In Cook, V. (ed.), Portraits of the L2 users. Sydney: Multilingual Matters LTD.

Collins, B., \& Mees, I. M. (1999). The Phonetics of English and Dutch. (4th ed.) Leiden: Brill.

Creswell, J. W. (2014). A Concise Introduction to Mixed Methods Research. SAGE Publications.

Dalton, D. (2002). Some Techniques for Teaching Pronunciation. http://iteslj.org/Techniques/Dalton_Pronunciation.html

Dalton, C., \& Seidhofer, B. (1994). Pronunciation. Oxford, UK: Oxford University Press.

Dauer, R. M. (2005). The Lingua Franca Core: A New Model for Pronunciation Instruction? TESOL Quarterly, 39(5), 540-550.

Derwing, T. (2003). What do ESL students say about their accents?.Canadian Modern Language Review, 59(4), 547-567.

Derwing,T., Munro, M., \& Wiebe, G. (1998). Evidence in favour of a broad framework for 


\section{Mll Macrothink}

pronunciation instruction. Language Learning, 48(3), 393-410.

Dörnyei, Z. (2007). Research methods in applied linguistics. Oxford: Oxford University Press.

Gilbert, J. (1984). Clear Speech. Pronunciation and Listening Comprehension in American English. Student's Book. Cambridge: CUP.

Hammond, R. M., Eckman, F. R., Highland, D., Lee, P. W., Mileham, J., \& Weber, R. R. (1995). Foreign accent and phonetic interference: The application of linguistic research to the teaching of second language pronunciation. Second language acquisition theory and pedagogy, 293-304.

Howatt, A. P. R., \& Widdowson, H. G. (2004). A History of ELT. Oxford University Press.

Jenkins, J. (2000). The Phonology of English as an International Language: new models, new norms, new goals. Oxford, UK. Oxfor University Press.

Jenkins, J. (2002). A sociolinguistically based, empirically researched pronunciation syllabus for English as an international language. Applied Linguistics, 23, 83-103.

Jenkins, J. (2005). Implementing an international approach to English pronunciation: The role of teacher attitudes and identity. TESOL Quarterly, 39, 535-543.

Jenkins, J. (2006). Global intelligibility and local diversity: possibility or paradox? In R. Rubdi, \& M. Saroceni, (Eds.), English in the world: Globalrules, global roles (pp. 32-39). London: Continuum.

Kharma, N. N., \& Hajjaj, A. H. (1989). Use of the mother tongue in the ESL classroom. International Review of Applied Linguistics, 27(3), 223-235.

Nayef, K., \& Hajjaj, A. (1997). Errors in English among Arabic speakers: Analysis and remedy, 129-142. Beirut, Lebanon: York Press and Librainie du Liban.

Krashen, S. D. (1981). Second language acquisition and second language learning. Oxford: Pergamon.

Larsen-Freeman, D. (1991). Second language acquisition research: Staking out the territory. TESOL Quarterly, 25(2), 315-339.

Lenneberg, E. (1967). Biological foundations of language. New York: Wiley.

Levis, J. M. (2005). Changingcontexts and shifting paradigms in pronunciation teaching. TESOL Quarterly, 39(3), 543-560.

Loup, G. (2005). Age in Second Language Development. In E. Hinkel (Ed.), Handbook of Second Language Learning and Teaching (pp. 419-439). Mahwah, NJ: Lawrence Erlbaum.

Miller, S. (2000). Looking at Progress in a Pronunciation Class. TESOL Matters, 10, No. 2

Morley, J. (1991). The Pronunciation Component in Teaching English to Speakers of Other Languages, TESOL Quarterly, 25(3), 481-520. 
Mousa, A. Ibrahim. (1994). The interphonology of Saudi learners of English. Ph. D. Thesis, University of Essex.

Moyer, A. (1999). Ultimate Attainment in L2 Phonology: The Critical Factors of Age Motivation and Instruction. Studies in Second Language Acquisition, 21, 81-108.

Munro, M., \& Derwing, T. (1995). Foreign accent, comprehensibility, and intelligibility in the speech of second language learners. Language Learning, 45, 73-97.

Munro, M., \& Derwing, T. M. (1999). Foreign accent, comprehensibility, and intelligibility in the speech of second language learners. Language Learning, 49(1), 285-310.

Nelson, C. (2008). Intelligibility since 1969. World Englishes, 27(3), 297-308.

Odin, T. (1989). Language Transfer: Cross-Linguistic Influence in Language Learning. New York: Cambridge University Press.

Postovsky, V. (1974). Effects of delay in oral practice at the beginning of second language learning. Modern Language Journal, 58(3), 229-239

Purcell, E. \& Suter. R. (1980). Predictors of pronunciation accuracy: A reexamination. Language Learning, 30(2) 271-87.

Scarcella, R. \& Oxford, R..L. (1994). Second Language Pronunciation: State of the Art in Instruction. System, 22(2), 221-230.

Scovel, T. (2000). A critical review of the critical period research. Annual Review of Applied Linguistics, 20, 213-223.

Seidlhofer, B. (2001). Pronunciation. In R. Carter and D. Nunan (eds.), The Cambridge guide to teaching English to speakers of other languages, Cambridge: Cambridge University Press, pp. 56-65.

Singleton, D., \& Lengyel Z. (1995). The age factor in second language acquisition: A critical look at the Critical Period Hypothesis. Clevedon: Multilingual Matters.

Smith, L., \& Nelson, C. (1985). International intelligibility of English: Directions and resources. World Englishes, 4, 333-342.

Swan, M., \& Smith, B. (2001). Learner English: A Teacher's Guide to Interference and Other Problems ( $2^{\text {nd }}$ ed.). Cambridge: Cambridge University Press.

Suter, R. (1976). Predicators of Pronunciation accuracy in second language learning. Language Learning, 26, 233-53.

Timmis, I. (2002). Native speaker norms and international English: A Classroom View. ELT Journal, 56(3), 240-249.

Ur, P. (1996). A course in language teaching. Practice and theory. Cambridge University Press.

Weinberger, S. (1990). Minimal Segments in Second Language Phonology in A. James and J. 
Leather (Eds.), New Sounds 90, 137-179, Proceedings of the 1990 Amsterdam Symposium of the Acquisition of Second Language Speech: University of Amsterdam.

Wells, J. (2005). Goals in teaching English pronunciation. In Dziubalska-kolaczyk, K. \& Przedlacka, J. (eds.), English pronunciation models: A changing scene. Oxford: Peter Lang.

Wong, R. (1993). Pronunciation Myths and Facts. English Teaching Forum, Oct. 1993, 45-46.

Zoghbor, W. S. K. (2011). The effectiveness of the Lingua Franca Core (LFC) in improving the perceived intelligibility and perceived comprehensibility of Arab learners at post-secondary level (Doctoral dissertation, University of Leicester). https://lra.le.ac.uk/handle/2381/9635?mode=full

\section{Copyright Disclaimer}

Copyright for this article is retained by the author(s), with first publication rights granted to the journal.

This is an open-access article distributed under the terms and conditions of the Creative Commons Attribution license (http://creativecommons.org/licenses/by/3.0/). 